\title{
Ameliorating Plant Available Water by Addition of Treated Palm Oil Mill Effluent (POME) Sludge on Entisols
}

\author{
Mohd Nizar Khairuddin ${ }^{1,2,3}$, Isharudin Md Isa ${ }^{2}$, Abd Jamil Zakaria ${ }^{1} \&$ Syahrizan Syahlan ${ }^{4}$ \\ ${ }^{1}$ Institute of Agricultural Production and Food Innovation, Universiti Sultan Zainal Abidin, Campus Tembila, \\ Besut, Terengganu, Malaysia \\ ${ }^{2}$ Department of Land Management, Faculty of Agriculture, Universiti Putra Malaysia, UPM Serdang, Selangor, \\ Malaysia \\ ${ }^{3}$ Faculty of Plantation and Agrotechnology, Universiti Teknologi MARA Pahang, Campus Jengka, Bandar Tun \\ Abdul Razak Jengka, Pahang, Malaysia \\ ${ }^{4}$ Faculty of Plantation and Agrotechnology, Universiti Teknologi MARA Melaka, Campus Jasin, Merlimau, \\ Melaka, Malaysia \\ Correspondence: Isharudin Md Isa, Department of Land Management, Faculty of Agriculture, Universiti Putra \\ Malaysia, 43400 UPM Serdang, Selangor, Malaysia. Tel: 60-125-016-806. E-mail: imi@upm.edu.my; \\ mohdnizar7@yahoo.com
}

Received: April 21, 2017

Accepted: May 22, $2017 \quad$ Online Published: June 15, 2017

doi:10.5539/jas.v9n7p218

URL: https://doi.org/10.5539/jas.v9n7p218

\begin{abstract}
Palm oil mill contributed a significant benefit to agro-based industry and social-economic for Malaysia. The treated POME sludge was produced from the open treatment ponds and palm oil mill effluent (POME) without any treatment is considered as a polluted wastewater. This study is to determine the effect of POME sludge on Entisols for plant available water (PAW). The data obtained from this study were selected to measure physicochemical parameters (bulk density, porosity, compaction, organic matter), hydraulic parameter (hydraulic conductivity, hydraulic capacity and water retention) to determine the PAW. The POME sludge from different treatment ponds (control, mixing pond, anaerobic pond, facultative pond, algae pond and dumping pond) was applied to the Zea mays (Hibrimas) as a test crops. The results showed that maize treated with POME sludge from the dumping pond indicated significant difference on soil organic matter, bulk density, porosity, soil compaction and plant available water compared to mixing and anaerobic ponds. As a conclusion, POME sludge from the dumping might improve soil physical properties of Entisols. The dumping pond sludge has significant potential to be used as an organic amendment for plant growth in the future.
\end{abstract}

Keywords: POME sludge, selected soil physical properties, plant available water

\section{Introduction}

In Malaysia, palm oil industry has contributed almost RM53 billion annually and expected to achieve RM178 billion in 2020 (MPOB, 2010). According to MPOB (2015), nearly 415 mills were operating in Peninsular Malaysia, Sabah and Sarawak to process all the fresh fruit bunches. However, the fresh fruit bunch could produce 26.7 million tonnes of solid waste from the palm oil such as empty fruit bunches (EFB), palm pressed fibres (PPF) and palm oil mill effluent (POME) (Yacob et al., 2005). It is estimated that nearly $50-60 \%$ of palm oil waste is POME (Baharuddin et al., 2010).

In the mills, POME was treated in the treatment ponds before it was discharged into the river. After treated, POME produced sediment in the treatment ponds and it was called as POME sludge. According to Khairuddin et al. (2016), the POME sludge was consisted of some nutrients including nitrogen, potassium, sulfur and carbon that can be utilized as an organic fertilizer. It has high moisture content and the $\mathrm{pH}$ of 8.4. In addition, the heavy metal content was confirmed at the safety level to use and followed the standard requirement by Codex Alimentarius Commission (FAO/WHO) (2001).

In this study, Rasau series based on USDA soil taxonomy known as Entisols was used to observe the effect of treated POME sludge on selected soil physical properties and hydraulic characteristics after application of treatments. Gasim et al. (2011) stated that Rasau series was consisted of mainly sandy loam and low organic 
matter content. Mostly, Rasau series was characterized as sandy soil texture with more than $54 \%$ of sand, silt is around $30 \%-32 \%$ and the clay content is with an average of $13 \%$. The soil physical properties such as bulk density, soil porosity, soil compaction, hydraulic properties, soil losses and yield were observed in this experiment.

Finding from this research was expected to enhance soil physical properties and improves fertility status of the soil by addition of organic matter. According to Dexter (1988), organic matter content affected the soil bulk density and soil compaction. El-Shakweer et al. (2008) also reported that the organic matter was able to increase soil porosity and infiltration rate. Hydraulic properties is been observed for determine the hydraulic conductivity and capacity in the soil. According to Hati and Bandyoopadhay (2011), they reported that addition of organic matter results increase aggregation and pore volume has positive effect on the saturated hydraulic conductivity of the soil. Improvement of soil physical and hydraulic properties would increase crop yield and quality.

In this study, the plant available water (PAW) is important to justify the difference in water content between field capacity and permanent wilting point in treatment and soil. In addition, by determine the quality and quantity of the plant available water and effectiveness of nutrient uptake in the soil that suitable for plant (Karlen et al., 1994). This also response for yield and phenology is closely related to plant available water capacity (Yang et al., 2014).

The objectives of this study were to determine the effect of treated POME sludge from mixing pond (MP), anaerobic pond (ANP), facultative pond (FP), algae pond (ALP), dumping pond (DP) and un-amended soil (Control) on soil physical properties and plant available water on Rasau series (Entisols).

\section{Method}

The experimental site was located at Research Farm of the Universiti Teknologi MARA Pahang, Campus Jengka, Pahang, Malaysia $\left(3.7562^{\circ} \mathrm{N}, 102.5611^{\circ} \mathrm{E}\right)$ for a period of February 2015 to June 2016. The POME sludge samples were taken from palm oil mill, Felda Jengka 8, Bandar Tun Abdul Razak Jengka, Pahang, Malaysia from different treatment ponds system (mixing, anaerobic, facultative, algae and dumping). The POME treatment system was set up at different Hydraulic Retention Time (HRT) process such as: cooling ponds (1 day), mixing ponds ( 2 days), anaerobic ponds (45 days), facultative ponds ( 20 days) and algae ponds ( 7 days). The dumping ponds was used as dislodging sediment for maintenance purposes two times a year.

The soil and POME sludge was dried, powdered and sieved through a $2 \mathrm{~mm}$ size. The Rasau soil series (Entisols) was dug up from $10 \mathrm{~cm}$ deep and dried, homogenized and sieved. The study was conducted consisted in polybag $16 \times 20 \mathrm{~cm}$ and planted with Zea mays (Hibrimas variety) in randomized complete blocks design (RCBD). Treatments in the amount of $50 \mathrm{~g}$ per polybag with different POME sludge (mixing, anaerobic, facultative, algae and dumping) were used as soil amendments with un-amended soil as control (C).

Bulk density was measured using $10 \mathrm{~g}$ of soil sample that was dried in the oven at $105^{\circ} \mathrm{C}$ and transfer into a measuring cylinder and gently tapped for compaction $\left(\mathrm{g} \mathrm{cm}^{-3}\right)$ (Radojevic \& Bashkin, 2006). Soil porosity test was carried out using a cylindrical ring of $100 \mathrm{~cm}^{3}$ volume with three replicates to determine a total porosity by the core method (Huang et al., 2005). Meanwhile, soil compaction test was used to determine the compaction status of the soil samples (Torbin et al., 1995).

To determine the soil hydraulic properties, RETC modeling was used based on Van Genuchten - Mualem, A (m $=1-1 / \mathrm{n})($ Van Genuchten, 1980):

$$
\theta=\theta \mathrm{r}+\frac{\theta \mathrm{s}-\theta \mathrm{r}}{[1+(\alpha \mathrm{h}) \mathrm{n}] \mathrm{m}}
$$

The water retention curve model was used to describe the soil water retention function where the subscripts of $r$ and s denoted as residual and saturated water contents, respectively. According to Van Genuchten et al. (1991), five independent parameters $(\theta r, \theta s, \alpha, n, m)$ and that the residual and saturated water contents are considered here as an empirical parameters. They are defined the retention model, and fitted to observe the data using water retention model (Van Genuchten et al., 1991). The most general formulation arises when the parameters $\mathrm{m}$ and $\mathrm{n}$ are assumed to be independent. The parameters are estimated with an algorithm described by Marquardt (1963).

Statistical analyses were conducted using SAS 9.4 statistical package (SAS, 2007). Analysis of variance (ANOVA) was conducted to test the treatments effect while means of treatment were compared using Tukey test at $\mathrm{P}<0.05$. 


\section{Results and Discussion}

\subsection{Selected Physiochemical Properties}

Table 1 shows the changes of POME sludge's bulk density from the different treatment ponds. In general, the highest bulk density was identified in control (C) $\left(1.44 \mathrm{~g} \mathrm{~cm}^{-3}\right), \operatorname{MP}\left(1.27 \mathrm{~g} \mathrm{~cm}^{-3}\right), \operatorname{ANP}\left(1.26 \mathrm{~g} \mathrm{~cm}^{-3}\right), \operatorname{FP}(1.23 \mathrm{~g}$ $\left.\mathrm{cm}^{-3}\right)$, ALP $\left(1.19 \mathrm{~g} \mathrm{~cm}^{-3}\right)$ and DP $\left(1.03 \mathrm{~g} \mathrm{~cm}^{-3}\right)$. According to USDA (2008), loose, porous soils and rich in organic matter was found as low bulk density. Moreover, Khalid et al. (1992) clarified that the effect of organic matter on the reduction of dry bulk density in soil was similar to the dumping pond (DP treatment) in this experiment.

The soil porosity presented in Table 1 increased significantly in C (45\%) and DP (61\%), respectively, whereas no significant difference was reported in MP (52\%), ANP (52\%), FP (53\%) and ALP (54\%). According to Pagliai et al. (1993), a soil structure will improve with the increased of soil porosity. Soil compaction analysis revealed that there was significant difference of compaction in each treatment (Table 1).

The study showed that compaction status was declining from MP $(224.08 \mathrm{kPa})>$ ANP $(172.37 \mathrm{kPa})>$ DP $(115.49 \mathrm{kPa})$ treatments compared to the control $(448.17 \mathrm{kPa})$. However, there was no significant changes observed in FP (163.75 kPa) and ALP (163.75 kPa). Decreased in compaction was the indicator of high organic matter content in the POME sludge. In addition, soil compaction mostly related to soil bulk density (Panayiotopoulos et al., 1994) and similar result was observed in this experiment.

The organic matter content in DP treatment was 2.68\%, whereas for ALP, FP, ANP and MP there were 2.65\%, $2.32 \%, 2.32 \%$ and $2.01 \%$ reduction in each treatment compared to the control $(1.15 \%)$. Table 1 shows that there was significant difference between the DP, MP and control treatments, respectively. Thus, the POME sludge might increase organic matter content, decreased bulk density and provided more nutrients to the soil. According to Pascual, et al. (1997), organic amendments was shown a greater effect in decreasing the C:N ratio.

Table 1. Bulk density, soil porosity, soil compaction and organic matter in different POME sludge treatment

\begin{tabular}{lllllll}
\hline & Control & MP & ANP & FP & ALP & DP \\
\hline Bulk density $\left(\mathrm{g} / \mathrm{m}^{3}\right)$ & $1.44 \mathrm{a}$ & $1.27 \mathrm{ab}$ & $1.26 \mathrm{ab}$ & $1.23 \mathrm{~b}$ & $1.20 \mathrm{~b}$ & $1.03 \mathrm{c}$ \\
Porosity $(\%)$ & $45.03 \mathrm{c}$ & $52.08 \mathrm{~b}$ & $52.45 \mathrm{~b}$ & $53.68 \mathrm{~b}$ & $54.81 \mathrm{~b}$ & $61.32 \mathrm{a}$ \\
Soil compaction $(\mathrm{kPa})$ & $448.16 \mathrm{a}$ & $224.08 \mathrm{~b}$ & $172.37 \mathrm{bc}$ & $163.75 \mathrm{bc}$ & $163.75 \mathrm{bc}$ & $115.49 \mathrm{c}$ \\
Organic matter $(\%)$ & $1.15 \mathrm{c}$ & $2.01 \mathrm{~b}$ & $2.32 \mathrm{ab}$ & $2.32 \mathrm{ab}$ & $2.65 \mathrm{a}$ & $2.68 \mathrm{a}$ \\
\hline
\end{tabular}

Note. Means with the same letter are not significantly different at $\mathrm{p}<0.05$.

\subsection{Hydraulic Parameters}

Result of hydraulic characteristics of different POME sludge are presented in Table 2. Table 2 shows that there is a different texture, $\theta \mathrm{r}$ and $\theta$ s (residual and saturated soil water content), respectively, $\alpha$ and $\mathrm{n}$ are van Genuchten (1980) parameter, and Ks (hydraulic conductivity) of the Entisols in all treatments.

Table 2. Hydraulic parameter of van Genuchten Mualem, A $(\mathrm{m}=1-1 / \mathrm{n})$ equation for retention curve.

\begin{tabular}{lllllll}
\hline Treatment & Control & MP & ANP & FP & ALP & DP \\
\hline Sand $(\%)$ & 55 & 55 & 55 & 55 & 55 & 55 \\
Silt $(\%)$ & 32 & 32 & 32 & 32 & 32 & 32 \\
Silt $(\%)$ & 13 & 13 & 13 & 13 & 13 & 13 \\
$\theta \mathrm{r}\left(\mathrm{cm}^{3} / \mathrm{cm}^{3}\right)$ & 0.047 & 0.050 & 0.050 & 0.051 & 0.052 & 0.552 \\
$\theta \mathrm{s}\left(\mathrm{cm}^{3} / \mathrm{cm}^{3}\right)$ & 0.386 & 0.423 & 0.426 & 0.434 & 0.441 & 0.488 \\
$\alpha\left(1 / \mathrm{cm}^{3}\right)$ & 0.018 & 0.015 & 0.015 & 0.014 & 0.014 & 0.012 \\
$\mathrm{n}(-)$ & 1.452 & 1.480 & 1.481 & 1.482 & 1.483 & 1.479 \\
Ks $(\mathrm{cm} /$ day $)$ & 29.64 & 56.38 & 58.54 & 66.07 & 74.03 & 143.35 \\
\hline
\end{tabular}

There was significant different in hydraulic conductivity in each treatment applied followed by ALP (74.03 $\mathrm{cm} /$ day), FP (66.07 cm/day), ANP $(58.54 \mathrm{~cm} /$ day) and MP treatments $(56.38 \mathrm{~cm} /$ day) (Figure 1). There was 
significant different of the hydraulic conductivity $(\mathrm{Ks})$ in DP $(143.35 \mathrm{~cm} /$ day $)$ that was due to low bulk density existed in the dumping pond sludge treatment.

Correlation analysis revealed that hydraulic conductivity and bulk density was highly correlated $\left(\mathrm{R}^{2}=0.925\right)$ (Figure 2). According to Gwenzi et al. (2011) attributed the incorporating of bulk density and soil texture (silt and clay) was important to determine the hydraulic conductivity in the soil residue. Therefore, high hydraulic conductivity (Ks) could cause the decreased in soil bulk density and increased the total porosity. Figure 2 indicated that the organic matter content was increased, control $(1.15 \%)<$ MP $(2.01 \%)<$ ALP $(2.32 \%)<$ FP $(2.33 \%)<\operatorname{ALP}(2.65 \%)<\operatorname{DP}(2.68 \%)$ after application of treatments. Hati et al $(2011)$ identified that addition of organic amendment improved the aggregation status of the soil. Soil permeability is a function of effective pore volume, increased pore volume and influence the hydraulic conductivity of the soil (Hati et al., 2011). Similar results was found in this experiment by adding the treated POME sludge as a soil treatment.

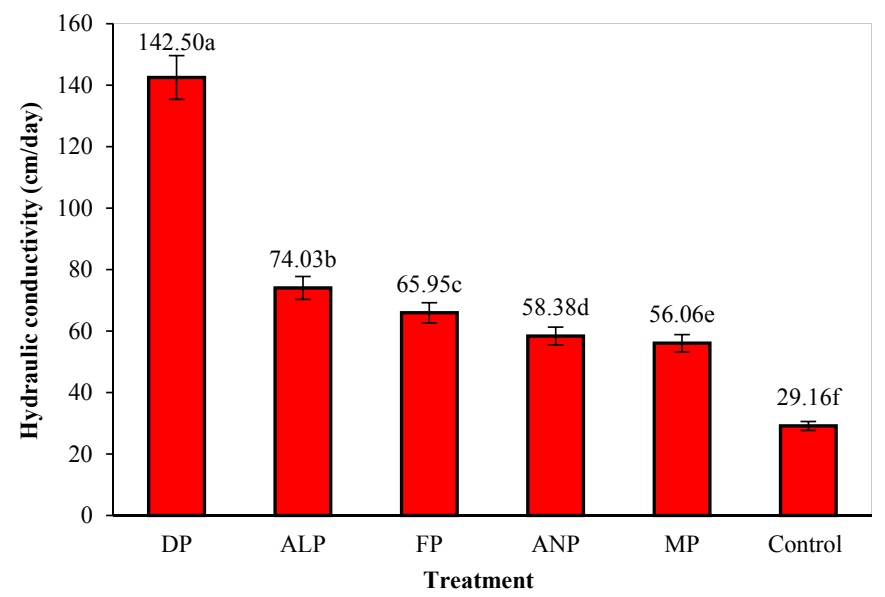

Figure 1. Hydraulic conductivity from different treatment ponds: control, MP, ANP, FP, ALP and DP Note. Means with the same letter are not significantly different at $\mathrm{p}<0.05$. 

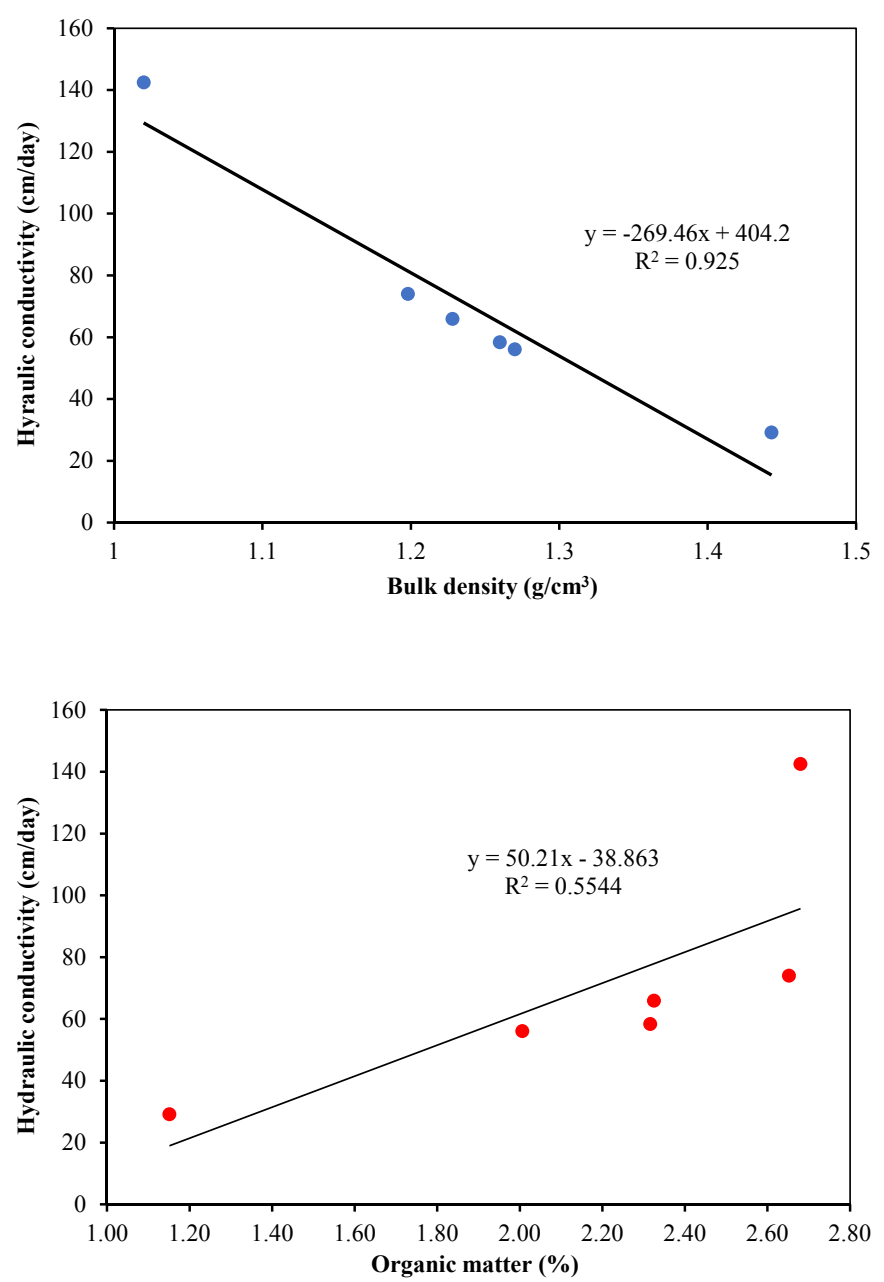

Figure 2. Correlation between hydraulic conductivity $\left(\mathrm{cm} /\right.$ day) measured by bulk density $\left(\mathrm{g} / \mathrm{cm}^{3}\right)$ and organic matter $(\%)$

\subsection{Plant Available Water (PAW)}

Figure 3 shows the relationship of water content and soil hydraulic conductivity. Based on the prediction of relative hydraulic conductivity, the soil water retention curve acts as a function in both of water content and hydraulic conductivity (Ks) as shown in Figure 3. Hydraulic properties among all treatments varied significantly in an increasing order: C $(29.64 \mathrm{~cm} /$ day $)<$ MP $(56.38 \mathrm{~cm} /$ day $)<\operatorname{ANP}(58.54 \mathrm{~cm} /$ day $)<$ FP $(66.07 \mathrm{~cm} /$ day $)<$ $\operatorname{ALP}(74.03 \mathrm{~cm} /$ day $)<\operatorname{DP}(143.35 \mathrm{~cm} /$ day $)$ respectively.

The increased in the hydraulic properties was correlated to the bulk density and soil organic matter. Besides that, the increased of water content might be associated with the treatment of C, MP, ANP, FP, ALP and DP which showed significant effect on the hydraulic conductivity based on Van Genuchtem-Mualem model, A (m = 1 $1 / \mathrm{n})$.

Therefore, the hydraulic conductivity was also increased due to the high organic matter content. It is proven by Nemes et al. (2005) that the organic matter might affect the pore-size distribution of the soil through soil structure development which also influenced the hydraulic conductivity. 


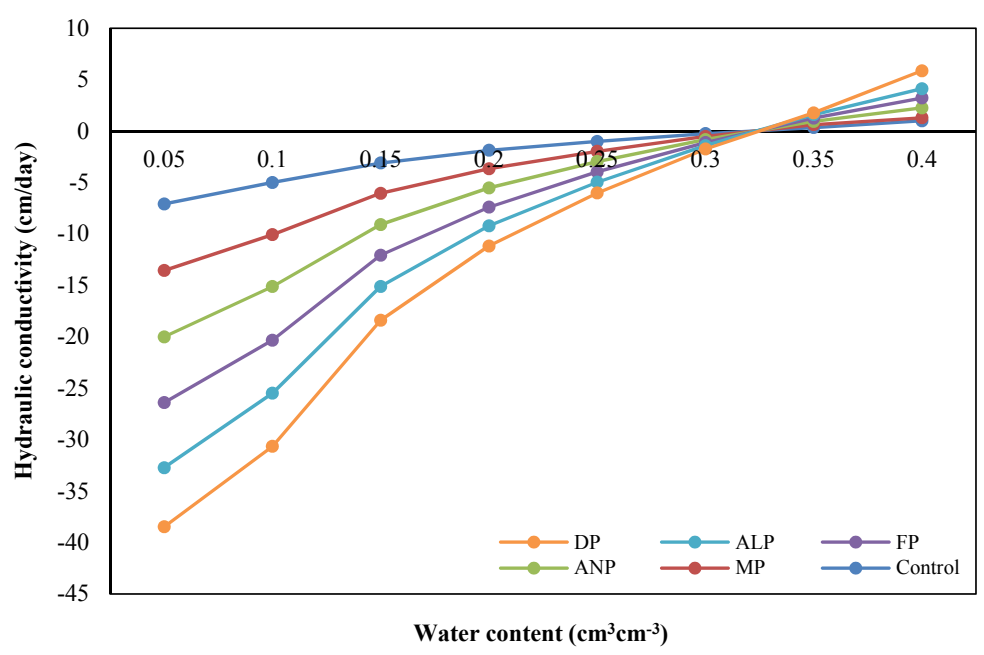

Figure 3. Relationship between water content $\left(\mathrm{cm}^{3} \mathrm{~cm}^{-3}\right)$ and hydraulic conductivity $(\mathrm{cm} /$ day) by RETC model in every treatment

According to Romano et al. (2002), while the time-based approximation is used to estimate field capacity, pressure head based approximation was used to estimate its capacity in the laboratory. For example, a commonly used approximation of water content at field capacity for coarse textured soil is $100 \mathrm{kPa}$ based on Romano et al. (2002). Figure 4 illustrates the plant available water among the treatments and there was significant difference in DP treatment $\left(0.22 \mathrm{~cm} \mathrm{~cm}^{-3}\right)$ compared to the control treatment $\left(0.16 \mathrm{~cm} \mathrm{~cm}^{-3}\right)$.

As the treatment was applied in this experiment, the trend of plant available water (PAW) increased in the following order: $\mathrm{C}<\mathrm{MP}<\mathrm{ANP}<\mathrm{FP}<\mathrm{ALP}<\mathrm{DP}$. The dumping pond (DP) treatment showed the highest amount of plant available water (PAW) compared to the other treatments.

This was due to the high organic matter content and low bulk density which increased the plant available water. The USDA (1998) stated that organic matter content increased the plant available water. As an example, each 1\% of organic matter added to the soil might increase $1.5 \%$ of plant available water (PAW).

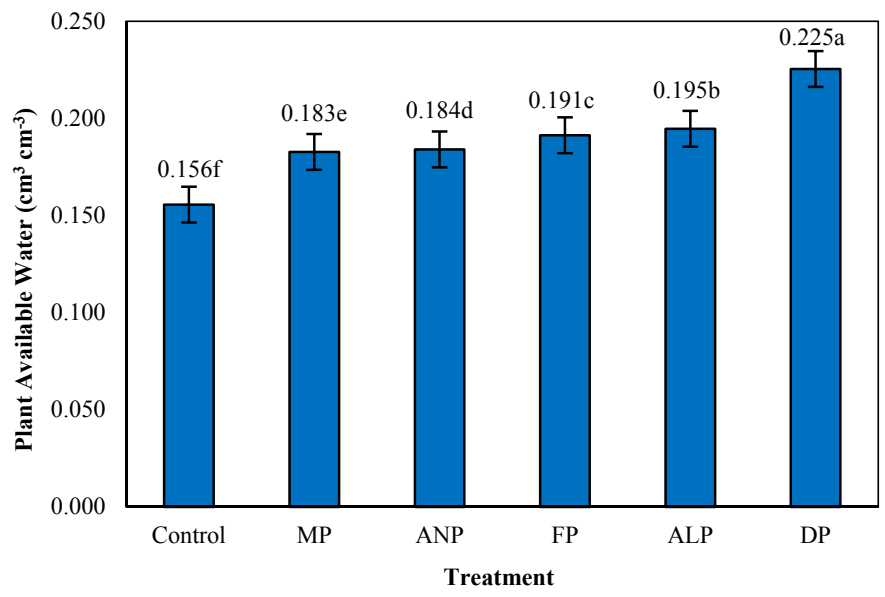

Figure 4. Plant Available Water (PAW) after treatment application

\section{Conclusion}

The Rasau soil series in this experiment was shown significant results after application of treatments in some selected soil physical properties. The significant results were observed on soil bulk density, porosity, soil compaction and organic matter with POME sludge from DP (dumping pond). With the present of high organic matter content, low bulk density and less compacted soil, DP treatment showed the best result in plant available water for plant growth. The other treatments were also shown significant effect on plant available water 
compared to the control treatment. As a conclusion, the DP treatment was the best treatment that could ameliorate soil physical properties, hydraulic properties and plant available water. Therefore, the growth performance of crops might also be increased significantly.

\section{Acknowledgements}

The authors would like to thanks, Universiti Sultan Zainal Abidin (UniSZA), Universiti Putra Malaysia (UPM) and Universiti Teknologi MARA Pahang for the facility assistance to conduct this project.

\section{References}

Baharuddin, A. S., Lim, S. H., Md Yusof, M. Z., Abdul Rahman, N. A., Md. Shah, U. K., Hassan, M. A., ... Shirai, Y. (2010). Effect of palm oil mill effluent (POME) anaerobic sludge based compost using fourier transform infrared (FTIR) and nuclear magnetic resonance (NMR) analysis. African Journal Biotechnology, 10(41), 2427-2436. https://doi.org/10.5897/AJB10.548

Codex Alimentarius Commission (FAO/WHO). (2001). Food additives and contaminants. Joint FAO/WHO Food Standards Program, Alinorm 01/12A, 1-289.

Dexter, A. R. (1988). Advances in characterization of soil structure. Soil Till. Res., 11, 199-238. https://doi.org/10.1016/0167-1987(88)90002-5

El-Shakweer, M. H. A., El-Sayad, E. A., \& Ewees, M. S. A. (2008). Soil and plant analysis as a guide for interpretation of the improvement efficiency of organic conditioners added to different soil in Egypt. Common. Soil Sci. Plant Anal., 29(11-14), 2067-2088. https://doi.org/10.1080/00103629809370094

Gasim, M. B., Ismail, B. S., Mir, S. I., Rahim, S. A., \& Toriman, M. E. (2011). The physico-chemical properties of four soil series in Tasik Chini, Pahang, Malaysia. Asian Journal of Earth Sciences, 4(2), 75. https://doi.org/10.3923/ajes.2011.75.84

Hati, K., \& Bandyoopadhay, K. (2011). Fertilizers (mineral, organic), effect on soil physical properties. Encyclopedia of Agrophysics (pp. 296-299). Springer Netherlands. https://doi.org/10.1007/978-90-4813585-1_201

Huang, Y., Wang, S. L., Feng, Z. W., Wang, H., \& Huang, H. (2005). Comparative study of selected soil properties following introduction of broad-leaf trees into clearfelled Chinese fir forest. Communications in Soil Science and Plant Analysis, 36, 1385-1403. https://doi.org/10.1081/CSS-200058468

Karlen, D. L., \& Stott, D. E. (1994). A framework for evaluating physical and chemical indicators of soil quality. Defining soil quality for a sustainable environment (definingsoilqua) (pp. 53-72).

Khairuddin, M. N., Zakaria, A. J., Isa, I. M., Jol, H., Rahman, W. M. N. W. A., \& Salleh, M. K. S. (2016). The Potential of Treated Palm Oil Mill Effluent (POME) Sludge as an Organic Fertilizer. Agrivita, 38(2), 142. https://doi.org/10.17503/agrivita.v38i2.753

Khalid, A. R., \& Mustafa, W. W. (1992). External benefits of environmental regulation: resource recovery and the utilisation of effluents. Environmentalist, 12(4), 277-285. https://doi.org/10.1007/BF01267698

Malaysian Palm Oil Board (MPOB). (2010). National Key Areas (NKEA): National Biogas Implementation (EPP5). Malaysia Palm Oil Board Kilang. Retrieved from http://mpob.com.my/National_Key_Economic_ Areas.pdf

Malaysian Palm Oil Board (MPOB). (2015). Palm oil production. Oil Palm Bulletin. MPOB News. Retrieved from http://www.mpob.gov.com

Marquardt, D. W. (1963). An algorithm for least-squares estimation of nonlinear parameters. J. Soc. Ind Appl. Math., 11, 431-441. https://doi.org/10.1137/0111030

Natural Resources Conservation Service (NRCS). (1998). Soil quality. Agronomy Technical Note, 6, 1-9. Retrieved from https://www.nrcs.usda.gov/Internet/fse_documents/nrcs142p2_053257.pdf

Nemes, A., Wosten, J. H. M., Bouma, J., \& Varallyay, G. (2005). Soil water balance scenario studies using predicted soil hydraulic parameters. Hydr. Proc. In Press. https://doi.org/10.1002/hyp.5934

Pagliai, M., \& De Nobili, M. (1993). Relationships between soil porosity, root development and soil enzyme activity in cultivated soils. Geoderma, 56, 243-256. https://doi.org/10.1016/0016-7061(93)90114-Z

Panayiotopoulos, K., Papadopoulou, C., \& Hatjiioannidou, A. (1994). Compaction and penetration resistance of an Alfisol and Entisol and their influence on root growth of maize seedlings. Soil Till. Res., 31, 323-337. https://doi.org/10.1016/0167-1987 (94)90039-6 
Pascual, J. A., Garcia, C., Hernandez, T., \& Ayuso, M. (1997). Changes in the microbial activity of an arid soil amended with urban organic wastes. Biology and Fertility of Soils, 24(4), 429-434. https://doi.org/10.1007/ s003740050268

Radojevic, M., \& Bashkin, V. N. (1999). Practical environmental analysis. Royal Society of Chemistry, RSC Publishing, London.

Romano, N., \& Santini, A. (2002). Water retention and storage: Field. In J. H. Dane, \& G. C. Topp (Eds.), Methods of Soil Analysis, Part 4: Physical Methods (pp. 721-738). Madison: Soil Science Society of America.

SAS Intstitute Inc. (2007). SAS/STAT software (Version 9), Cary, NC, USASAS Institute, Inc.

Torbin, R., Heirtzler, F., Lukasiewicz, M., \& Artzberger, T. (1995). Soil compaction meter (pp. 782-790). International Gas Research Conference. Retrieved from http://cat.inist.fr/?aModele=afficheN\&cpsidt=31 49221

United States Department of Agriculture (USDA). (2008). Soil bulk density/moisture/aeration (pp. 1-11). USDA Natural Resources Services. Retrieved from https://www.nrcs.usda.gov/Internet/FSE_DOCUMENTS/nrcs 142p2_050936.pdf

Van Genuchten, M. T. (1980). A closed-form equation for predicting the hydraulic conductivity of unsaturated soils. Soil Science Society of America Journal, 44(5), 892-898. https://doi.org/10.2136/sssaj1980.0361599 $5004400050002 \mathrm{x}$

Van Genuchten, M. Th., Leij, F. J., \& Yates, S. R. (1991). The RETC code for quantifying the hydraulic functions of unsaturated soils. U.S. Salinity Laboratory, U.S. Department of Agriculture, Agricultural Research Service Riverside, California USA.

Yacob, S., Hassan, M. A., Shirai, Y., Wakisakaa, M., \& Subash, S. (2005). Baseline study of methane emission from open digesting tanks of palm oil mill effluent treatment. Chemosphere, 59, 1575-1581. https://doi.org/ 10.1016/j.chemosphere.2004.11.040

Yang, Y., Liliu, D., Anwar, M. R., Zuo, H., \& Yang, Y. (2014). Impact of future climate change on wheat production in relation to plant-available water capacity in a semiaridenvironment. Theoretical and Applied Climatology, 115(3-4), 391-410. https://doi.org/10.1007/s00704-013-0895-z 


\section{Appendix}

Appendix 1. Bulk density, soil porosity, soil compaction and organic matter in different POME sludge treatment

\begin{tabular}{lllllll}
\hline & Control & MP & ANP & FP & ALP & DP \\
\hline Bulk density $\left(\mathrm{g} / \mathrm{m}^{3}\right)$ & $1.44 \mathrm{a}$ & $1.27 \mathrm{ab}$ & $1.26 \mathrm{ab}$ & $1.23 \mathrm{~b}$ & $1.20 \mathrm{~b}$ & $1.03 \mathrm{c}$ \\
Porosity $(\%)$ & $45.03 \mathrm{c}$ & $52.08 \mathrm{~b}$ & $52.45 \mathrm{~b}$ & $53.68 \mathrm{~b}$ & $54.81 \mathrm{~b}$ & $61.32 \mathrm{a}$ \\
Soil compaction $(\mathrm{kPa})$ & $448.16 \mathrm{a}$ & $224.08 \mathrm{~b}$ & $172.37 \mathrm{bc}$ & $163.75 \mathrm{bc}$ & $163.75 \mathrm{bc}$ & $115.49 \mathrm{c}$ \\
Organic matter $(\%)$ & $1.15 \mathrm{c}$ & $2.01 \mathrm{~b}$ & $2.32 \mathrm{ab}$ & $2.32 \mathrm{ab}$ & $2.65 \mathrm{a}$ & $2.68 \mathrm{a}$ \\
\hline
\end{tabular}

Note. MP: Mixing pond sludge; ANP: Anaerobic pond sludge; FP: Facultative pond sludge; ALP: Algae pond sludge; DP: Dumping pond sludge. Means with the same letter are not significantly different at $\mathrm{p}<0.05$.

Appendix 2. Hydraulic parameter of van Genuchten Mualem, A ( $\mathrm{m}=1-1 / \mathrm{n})$ equation for retention curve

\begin{tabular}{lllllll}
\hline Treatment & Control & MP & ANP & FP & ALP & DP \\
\hline Sand (\%) & 55 & 55 & 55 & 55 & 55 & 55 \\
Silt $(\%)$ & 32 & 32 & 32 & 32 & 32 & 32 \\
Silt $(\%)$ & 13 & 13 & 13 & 13 & 13 & 13 \\
$\theta \mathrm{r}\left(\mathrm{cm}^{3} / \mathrm{cm}^{3}\right)$ & 0.047 & 0.050 & 0.050 & 0.051 & 0.052 & 0.552 \\
$\theta \mathrm{s}\left(\mathrm{cm}^{3} / \mathrm{cm}^{3}\right)$ & 0.386 & 0.423 & 0.426 & 0.434 & 0.441 & 0.488 \\
$\alpha\left(1 / \mathrm{cm}^{3}\right.$ & 0.018 & 0.015 & 0.015 & 0.014 & 0.014 & 0.012 \\
$\mathrm{n}(-)$ & 1.452 & 1.480 & 1.481 & 1.482 & 1.483 & 1.479 \\
Ks $(\mathrm{cm} /$ day) & 29.64 & 56.38 & 58.54 & 66.07 & 74.03 & 143.35 \\
\hline
\end{tabular}

Note. MP: Mixing pond sludge; ANP: Anaerobic pond sludge; FP: Facultative pond sludge; ALP: Algae pond sludge; DP: Dumping pond sludge; $\theta$ r: Theta r; $\theta$ s: Theta s; $\alpha$ : Alpha; n: Volumetric water content; Ks: hydraulic conductivity.

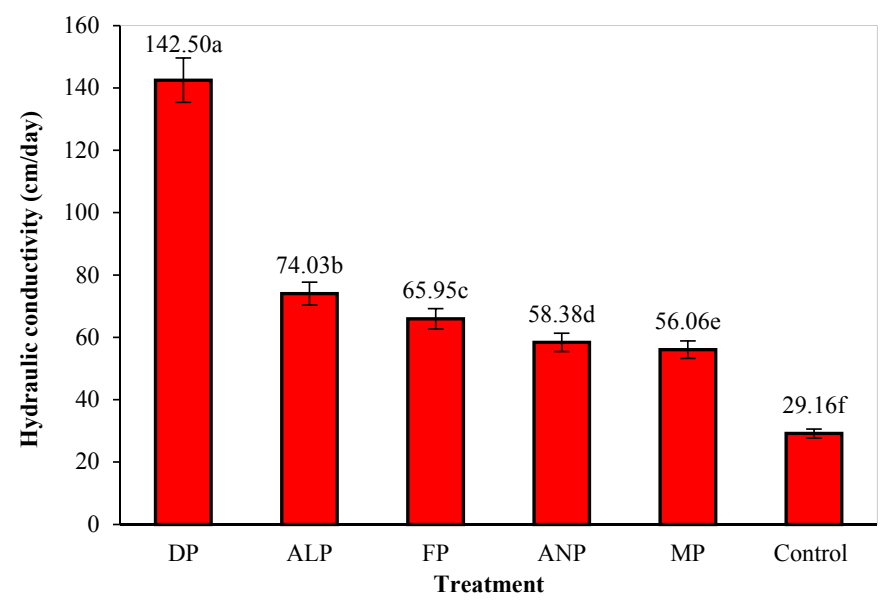

Appendix 3. Hydraulic conductivity from different treatment ponds: control, MP, ANP, FP, ALP and DP Note. Means with the same letter are not significantly different at $\mathrm{p}<0.05$. 

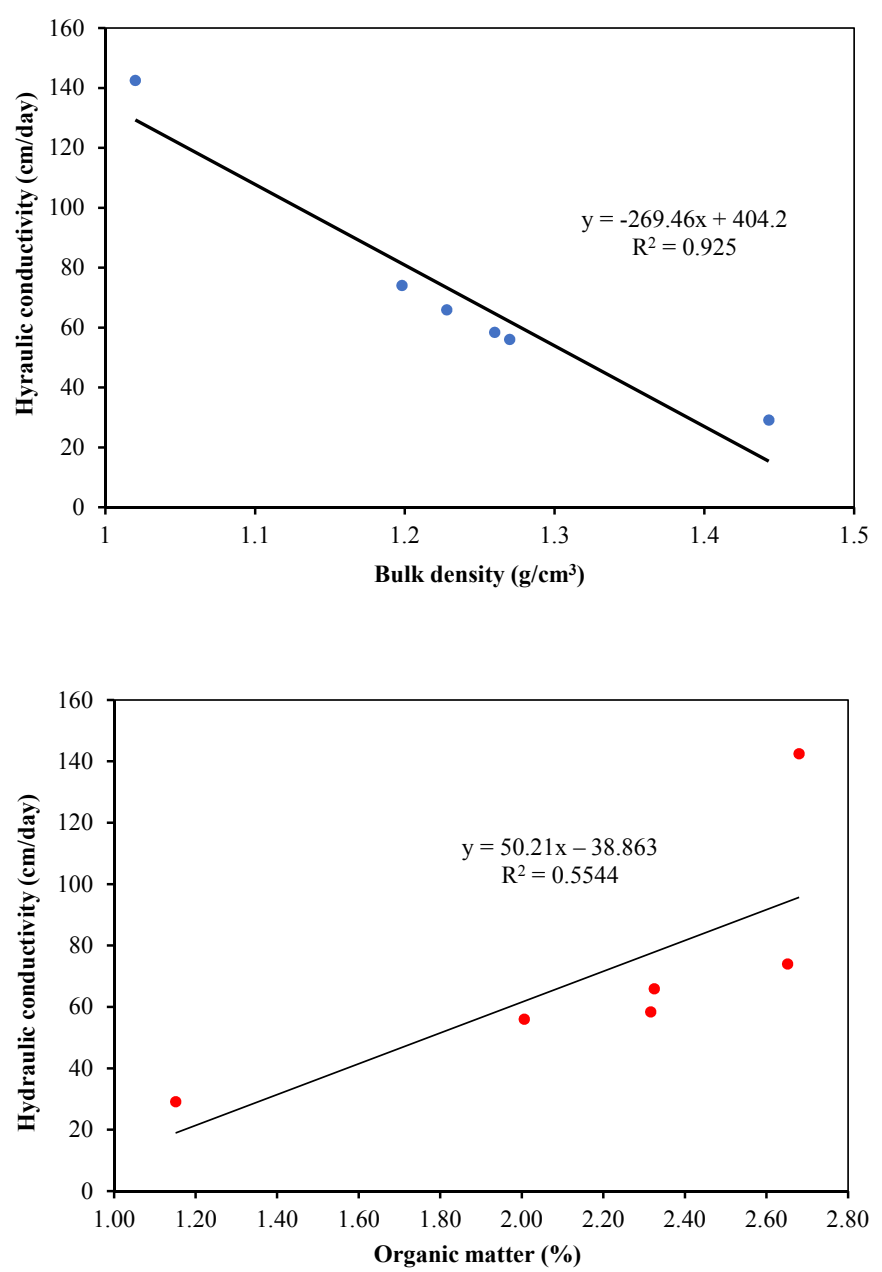

Appendix 4. Correlation between hydraulic conductivity $\left(\mathrm{cm} /\right.$ day) measured by bulk density $\left(\mathrm{g} / \mathrm{cm}^{3}\right)$ and organic matter (\%)

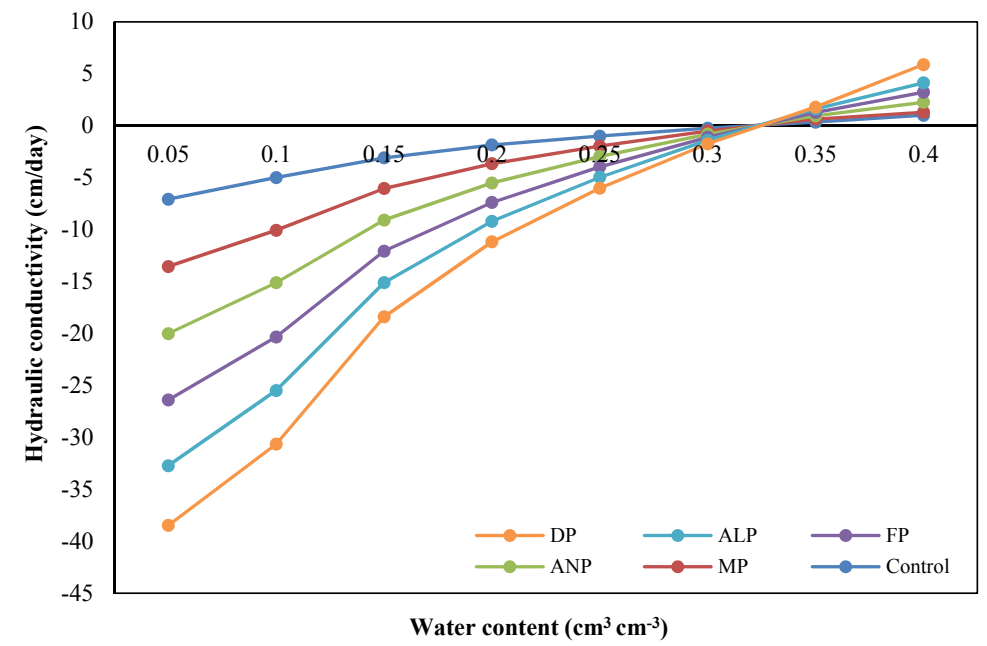

Appendix 5. Relationship between water content $\left(\mathrm{cm}^{3} \mathrm{~cm}^{-3}\right)$ and hydraulic conductivity ( $\mathrm{cm} /$ day) by RETC model in every treatment 


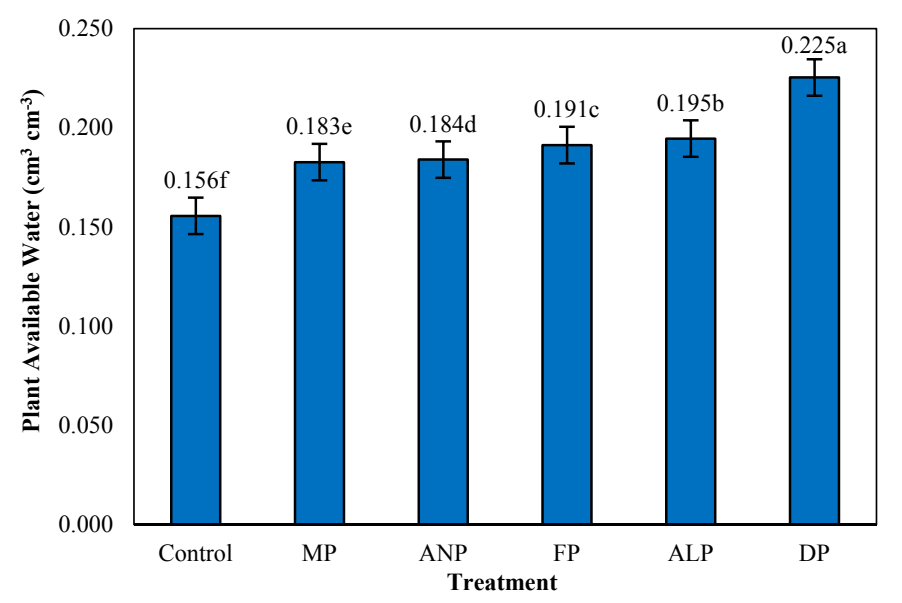

Appendix 6. Plant Available Water (PAW) after treatment application

\section{Copyrights}

Copyright for this article is retained by the author(s), with first publication rights granted to the journal.

This is an open-access article distributed under the terms and conditions of the Creative Commons Attribution license (http://creativecommons.org/licenses/by/4.0/). 